\title{
BEBERAPA FAKTOR YANG MEMPENGARUHI KEPATUHAN WAJIB PAJAK ORANG PRIBADI
}

\author{
Oleh: \\ Endang Kusdiah Ningsih, Bahdar Johan \\ Fakultas Ekonomi Universitas IBA Palembang \\ Jalan Mayor Ruslan Palembang
}

\begin{abstract}
Efforts to increase state revenues in the tax sector have many obstacles, among others, the level of taxpayer compliance is still low. Many factors that can affect the taxpayer compliance of the individual include taxpayer awareness, tax service and tax sanctions. Objects in this study are individual taxpayers at the Faculty of Engineering Sriwijaya University.

The purpose of this study is to determine the effect of taxpayer awareness, tax service and tax sanctions on Personal Taxpayer compliance in the Faculty of Engineering Sriwijaya University. The type of research used is a type of causal research that is intended to reveal the problems of cause and effect. The sample used in this study is as many as 188 people taxpayers personally in the Faculty of Engineering Sriwijaya University.

Based on the results of existing research can be concluded that the consciousness of taxpayers have a positive but not significant impact on taxpayer compliance in the Faculty of Engineering Sriwijaya University. While for variable of Fiscal service and tax sanction have positive and significant effect to taxpayer compliance. This suggests that the higher the tax and tax sanction, the formal taxpayer compliance will be significantly higher.
\end{abstract}

\section{Keywords: Awareness, Fiscal Services, Tax Sanctions and Compliance}

\begin{abstract}
ABSTRAK
Upaya peningkatan penerimaan negara di sektor perpajakan memiliki banyak kendala, antara lain, tingkat kepatuhan wajib pajak masih rendah. Banyak faktor yang dapat mempengaruhi kepatuhan wajib pajak individu termasuk kesadaran wajib pajak, pelayanan perpajakan dan sanksi perpajakan. Objek dalam penelitian ini adalah pembayar pajak individu di Fakultas Teknik Universitas Sriwijaya.

Tujuan dari penelitian ini adalah untuk mengetahui pengaruh kesadaran wajib pajak, pelayanan perpajakan dan sanksi pajak terhadap kepatuhan Wajib Pajak Pribadi di lingkungan Fakultas Teknik Universitas Sriwijaya. Jenis penelitian yang digunakan adalah jenis penelitian kausal yang dimaksudkan untuk mengungkap permasalahan sebab dan akibat. Sampel yang digunakan dalam penelitian ini adalah sebanyak 188 orang wajib pajak pribadi di Fakultas Teknik Universitas Sriwijaya.

Berdasarkan hasil penelitian yang ada dapat disimpulkan bahwa kesadaran pembayar pajak memiliki dampak positif namun tidak signifikan terhadap kepatuhan wajib pajak di Fakultas Teknik Universitas Sriwijaya. Sedangkan untuk variabel pelayanan Fiskal dan
\end{abstract}


sanksi perpajakan berpengaruh positif dan signifikan terhadap kepatuhan wajib pajak. Hal ini menunjukkan bahwa semakin tinggi pajak dan sanksi pajak, kepatuhan wajib pajak formal akan jauh lebih tinggi.

Kata kunci: Kesadaran, Jasa Fiskal, Sanksi dan Kepatuhan Pajak

\section{PENDAHULUAN}

Pajak merupakan bagian yang cukup potensial sebagai penerimaan negara maupun daerah. Pajak yang dikelola pemerintah pusat merupakan sumber penerimaan negara di dalam APBN, sedangkan pajak yang dikelola pemerintah daerah merupakan sumber penerimaan daerah di dalam APBD. Pemerintah memiliki peranan penting dalam kehidupan ekonomi suatu negara. Pemerintah harus melakukan pengendalian terhadap kondisi yang tengah terjadi dan mengevaluasinya kemudian merancang suatu aturan untuk membuat perekonomian menjadi lebih baik. Dalam melaksanakan kegiatannya, negara memerlukan adanya aliran dana untuk menjalankan roda pemerintahan. Dana yang telah diperoleh dari beberapa sektor penerimaan APBN akan digunakan untuk keberlangsungan atau pengeluaran negara, baik itu pengeluaran rutin maupun pengeluaran pembangunan. Sektor pendapatan terbesar dalam pos APBN berasal dari penerimaan pajak yang masih potensial untuk terus ditingkatkan penerimaannya. Pemerintah harus memiliki manajemen yang baik dalam mengelola sumber dana yang telah diperoleh dari sektor pajak agar penggunaanya berjalan efektif dan efisien sehingga tidak terjadi penyalahgunaan

Usaha memaksimalkan penerimaan pajak tidak dapat hanya mengandalkan peran dari Ditjen Pajak maupun petugas pajak, tetapi dibutuhkan juga peran aktif dari para wajib pajak itu sendiri. Perubahan sistem perpajakan dari Official Assessment menjadi Self Assessment, memberikan kepercayaan wajib pajak untuk mendaftar, menghitung, membayar dan melaporkan kewajiban perpajakannya sendiri. Hal ini menjadikan kepatuhan dan kesadaran wajib pajak menjadi faktor yang sangat penting dalam hal untuk mencapai keberhasilan penerimaan pajak.

Sebelum era reformasi perpajakan, sistem pemungutan pajak yang ditetapkan adalah official assessment system. Sistem ini merupakan sistem pemungutan yang memberi wewenang kepada fiskus untuk menetapkan besarnya pajak yang terutang oleh wajib pajak (WP) (Tarjo dan Kusumawati, dalam Santi, 2012). Kelebihan dari sistem ini 
adalah segala risiko pajak yang akan timbul menjadi tanggung jawab fiskus, seperti terlambat membayar atau melapor dikarenakan keterlambatan fiskus menetapkan besarnya jumlahnya pajak terutang yang harus dibayar oleh Wajib Pajak. Kelemahan dari sistem ini adalah Wajib Pajak bersifat pasif mengikuti ketentuan dan ketetapan yang dikeluarkan oleh fiskus.

Usaha meningkatkan penerimaan negara disektor pajak mempunyai banyak kendala yaitu antara lain tingkat kepatuhan Wajib Pajak yang masih rendah, sehingga Wajib Pajak berusaha untuk membayar kewajiban pajaknya lebih kecil dari yang seharusnya dan juga masih banyak Wajib Pajak yang tidak melaporkan dan membayarkan pajaknya (Arum, 2012)..

Kesadaran untuk mematuhi ketentuan (hukum pajak) yang berlaku tentu menyangkut faktor-faktor apakah ketentuan tersebut telah diketahui, diakui, dihargai, dan ditaati. Penilaian positif Wajib Pajak terhadap pelaksanaan fungsi negara oleh pemerintah akan menggerakkan masyarakat untuk mematuhi kewajibannya untuk membayar pajak. maka dari itu kesadaran Wajib Pajak mengenai perpajakan sangat diperlukan guna meningkatkan kepatuhan Wajib Pajak.

Pelayanan fiskus yang baik diharapkan mampu meningkatkan kepatuhan wajib pajak. Dalam penelitian Supadmi (2010) disebutkan bahwa untuk meningkatkan kepatuhan wajib pajak dalam memenuhi kewajiban perpajakannya, kualitas pelayanan pajak harus ditingkatkan oleh aparat pajak. Pelayanan fiskus yang baik akan memberikan kenyamanan bagi wajib pajak. Keramah tamahan petugas pajak dan kemudahan dalam sistem informasi perpajakan termasuk dalam pelayanan perpajakan tersebut.

Objek dalam penelitian ini adalah wajib pajak orang pribadi di Fakultas Teknik Universitas Sriwijaya. Universitas ini merupakan universitas terbesar di Provinsi Sumatera Selatan dengan jumlah mahasiswanya sangat banyak didukung juga oleh tenaga pengajar dan pegawai yang cukup memadai. Tingkat kepatuhan wajib pajak di Fakultas Teknik Universitas Sriwijaya sudah cukup meningkat, hal ini terlihat dari peningkatan wajib pajak yang terdaftar di Fakultas Teknik Universitas Sriwijaya. Oleh karena itu, hal tersebut menarik perhatian untuk dilakukan penelitian terhadap wajib pajak di Fakultas Teknik Universitas Sriwijaya. Jumlah Wajib Pajak Orang Pribadi pada Fakultas Teknik Universitas Sriwijaya dilihat dari status jabatan adalah: 
Tabel 1. Data Wajib Pajak Orang Pribadi

Pada Fakuktas Teknik Universitas Sriwijaya

\begin{tabular}{ll}
\hline Status Jabatan & Jumlah WP \\
\hline Pegawai BLU & 98 \\
Pegawai PNS & 67 \\
Dosen & 191 \\
\hline Total & $\mathbf{3 5 6}$
\end{tabular}

Sumber : Fakultas Teknik Universitas Sriwijaya, 2017

Dari tabel di atas dapat dilihat bahwa jumlah wajib pajak orang pribadi di Fakultas Teknik Universitas Sriwijaya berjumlah 356 orang yang terdiri dari Pegawai BLU 98 orang, Pegawai PNS 67 orang dan dosen 191 orang. Hal ini merupakan salah satu pemicu pemerintah untuk terus melakukan peningkatan pelayanan pajak yang lebih baik supaya tingkat kepatuhan wajib pajak meningkat.

Banyak faktor yang dapat mempengaruhi wajib pajak orang pribadi di Fakultas Teknik Universitas Sriwijaya dalam melaporkan dan membayar pajak terutangnya. Diantaranya yaitu kurangnya kesadaran Wajib Pajak dalam melaporkan dan membayar pajak terutang sehingga Wajib Pajak berusaha untuk membayar kewajiban pajaknya lebih kecil dari yang seharusnya, yang kedua tentang pelayanan fiskus atau petugas pajak dan yang terakhir adanya sanksi perpajakan yang dapat membuat Wajib Pajak baik terpaksa atau tidak harus melaporkan dan membayar pajak terutangnya.

Penilaian positif Wajib Pajak pada Fakultas Teknik Universitas Sriwijaya terhadap pelaksanaan fungsi negara oleh pemerintah akan menggerakkan wajib pajak untuk mematuhi kewajibannya untuk membayar pajak. maka dari itu kesadaran Wajib Pajak Fakultas Teknik Universitas Sriwijaya mengenai perpajakan sangatlah diperlukan guna meningkatkan kepatuhan Wajib Pajak. Hal ini bertujuan untuk menciptakan wajib pajak yang memiliki kesadaran tinggi dan mengerti fungsi pajak, baik mengerti manfaat pajak untuk masyarakat umum diri pribadi, sehingga masyarakat akan sukarela dan disiplin membayar pajak tanpa paksaan. Namun, pada kenyataannya pengetahuan dan wawasan wajib pajak khususnya di Fakultas Teknik Universitas Sriwijaya akan sistem dan peraturan perpajakan masih kurang dan menyebabkan wajib pajak disini 
tidakmemahami bagaimana caranya melaksanakan kewajiban perpajakan mereka sehingga akhirnya tidak melaksanakan kewajibannya.

Banyak wajib pajak yang terdaftar di Fakultas Teknik Universitas Sriwijaya belum mengetahui kewajiban untuk melaporkan pajaknya sehingga terdapat wajib pajak yang terkena sanksi karena keterlambatan melaporkan pajaknya, sanksi berupa denda yang dikenakan bagi wajib pajak yang terlambat melapor pajaknya. Bentuk denda bagi para wajib pajak yang tidak memenuhi kewajibannya hingga batas akhir yang ditetapkan, nilai denda antara wajib pajak individu dan wajib pajak lembaga tidaklah sama, untuk wajib pajak individu jika melewati batas 31 maret dikenakan denda Rp 500 ribu sedangkan bagi lembaga melewati batas akhir 31 april dikenakan denda Rp 1 juta.

Penelitian tentang kepatuhan wajib pajak telah dilakukan oleh beberapa peneliti.Namun sasaran penelitian sebelumnya lebih banyak pada sektor usaha kecil menengah dan wajib pajak badan. Widayati dan Nurlis (2010) meneliti kepatuhan usaha kecil menengah dalam pelaporan pajaknya. Adapun Muliari dan Setiawan (2010) menggunakan wajib pajak orang pribadi dalam penelitian yang dilakukannya. Namun, wajib pajak orang pribadi dalam penelitian tersebut merupakan wajib pajak orang pribadi secara keseluruhan. Berbeda dengan penelitian sebelumnya, sasaran dalam penelitian ini akan difokuskan pada wajib pajak orang pribadi yang melakukan kegiatan usaha dan pekerjaan bebas.

Berdasarkan latar belakang di atas permasalahan yang ingin dikaji dalam penelitian ini adalah Bagaimana Pengaruh Kesadaran Wajib Pajak, Pelayanan Fiskus dan Sanksi Pajak Terhadap Kepatuhan Wajib Pajak Orang Pribadi Di Fakultas Teknik Universitas Sriwijaya?

\section{KERANGKA TEORITIS}

Penelitian terdahulu dilakukan oleh Santi (2012). Santi melakukan penelitian mengenai Analisis Pengaruh Kesadaran Perpajakan, Sikap Rasional, Lingkungan, Sanksi Denda dan Sikap Fiskus Terhadap Kepatuhan Wajib Pajak Pada WPOP di Wilayah KPP Pratama Semarang. Analisis dilakukan dengan regresi linear berganda. Variabel bebas yang digunakan adalah kesadaran perpajakan, sikap rasional, lingkungan, sanksi denda, dan sikap fiskus. Sedangkan variabel terikatnya adalah kepatuhan wajib pajak. Hasil 
penelitiannya adalah (1) seluruh hipotesis diterima, yakni kesadaran perpajakan, sikap rasional, lingkungan, sanksi denda, dan sikap fiskus berpengaruh positif dan signifikan terhadap kepatuhan pajak, baik secara parsial dan simultan. Variabel sikap fiskus memberikan pengaruh yang paling besar terhadap kepatuhan pajak karena memiliki nilai beta 0,284 , sedangkan variabel sikap rasional memberikan pengaruh yang paling kecil terhadap kepatuhan pajak karena memiliki nilai beta 0,162 dan (2) penelitian ini juga mengungkapkan bahwa variabel kesadaran perpajakan, sikap rasional, lingkungan, sanksi denda dan sikap fiskus dapat digunakan untuk menjelaskan kepatuhan pajak sebesar $57,2 \%$ sedangkan sisanya sebesar $42,8 \%$ dijelaskan oleh faktor lain di luar model persamaan regresi.

Menurut Tryana (2013) menyatakan bahwa hasil penelitian kesadaran perpajakan berpengaruh signifikan terhadap kepatuhan wajib pajak orang pribadi dikarenakan kesadaran perpajakan hanya akan menjadi bahan pertimbangan bagi mereka untuk menyetorkan nominal pajak yang dibebankan kepada wajib pajak tersebut. Hasil penelitian Muliari dan Setiawan (2010) menjelaskan bahwa kesadaran wajib pajak secara parsial berpengaruh positif dan signifikan pada kepatuhan pelaporan wajib pajak orang pribadi.

Pelayanan yang berkualitas menurut Supadmi (2010) adalah pelayanan yang dapat memberikan kepuasan kepada wajib pajak dan tetap dalam batas memenuhi standar pelayanan yang dapat dipertanggungjawabkan serta harus dilakukan secara terus menerus. Menurut Robinson (2012) yang melakukan pengujian kualitas pelayanan pajak dan tingkat kepatuhan wajib pajak orang pribadi. Dalam penelitian ini dihasilkan terdapat pengaruh positif antara kualitas pelayanan pajak terhadap tingkat kepatuhan wajib pajak orang pribadi.

Muliari dan Setiawan (2010) menjelaskan bahwa sanksi perpajakan merupakan jaminan bahwa ketentuan peraturan perundang-undangan perpajakan (norma perpajakan) akan dituruti/ditaati/dipatuhi, dengan kata lain sanksi perpajakan merupakan alat pencegah agar wajib pajak tidak melanggar norma perpajakan. Oleh karena itu, pandangan wajib pajak mengenai sanksi perpajakan diduga akan mempengaruhi kepatuhan wajib pajak dalam membayar pajak. Kepatuhan Wajib Pajak menurut 
Nurmantu dalam Rahayu (2010:138) adalah suatu keadaan di mana Wajib Pajak memenuhi semua kewajiban perpajakan dan melaksanakan hak perpajakannya.

Dalam penelitian ini akan berusaha dijelaskan mengenai pengaruh kesadaran wajib pajak, pelayanan fiskus, dan sanksi pajak terhadap kepatuhan wajib pajak orang pribadi di Fakultas Teknik Universitas Sriwijaya. Kesadaran wajib pajak, pelayanan fiskus, dan sanksi pajak diduga akan berpengaruh terhadap kepatuhan wajib pajak. Kerangka pemikiran teoritis penelitian ini disajikan pada gambar berikut:

Gambar 1

Kerangka Pemikiran Teoritis

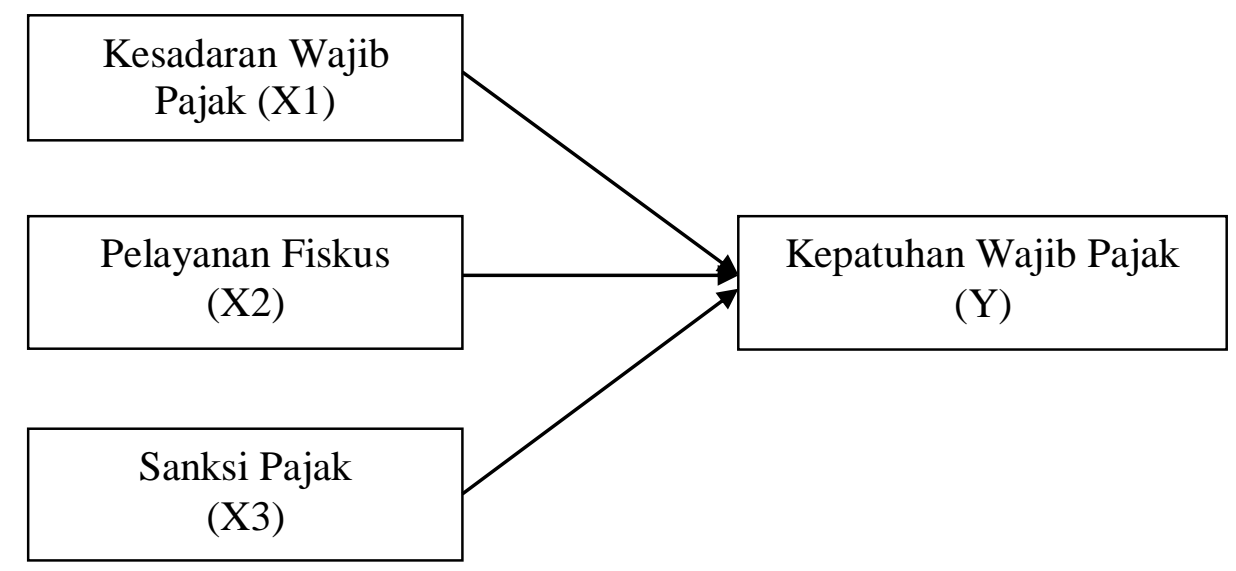

\section{METODE PENELITIAN}

Populasi dalam penelitian ini adalah wajib pajak orang pribadi pada Fakultas Teknik Universitas Sriwijaya Tahun 2017sebanyak 356 orang. Metode yang digunakan untuk menentukkan sampel oleh peneliti adalah pendekatan Slovin sehingga diperoleh $\mathrm{n}=$ 188 (dibulatkan)

Metode analisis yang digunakan dalam penelitian ini adalah: Analisis Kuantitatif, yaitu Uji Asumsi Klasik, Analisis Regresi Linier Berganda dan Uji Hipotesis dan Koefisien Determinasi. 


\section{HASIL DAN PEMBAHASAN}

\section{Uji Normalitas}

Hasil uji normalitas pada penelitian ini dapat dilihat pada gambar 6.1. Berdasarkan tampilan grafik Normal P-Plot tersebut, dapat disimpulkan bahwa pola grafik normal terlihat dari titik-titik yang menyebar di sekitar garis diagonal dan penyebarannya mengikuti arah garis diagonal. Berdasarkan grafik Normal P-plot, menunjukkan bahwa model regresi layak dipakai dalam penelitian ini karena memenuhi asumsi normalitas

\section{Uji Multikoleniaritas}

Untuk mengetahui ada atau tidaknya multikolinieritas maka dapat dilihat dari nilai Varians Inflation Factor (VIF). Bila angka VIF ada yang melebihi 10 berarti terjadinya multikolinieritas. Berdasarkan hasil uji multikoleniaritas menunjukkan bahwa nilai tolerance dari ketiga variabel independen berada di atas 0.10 dan VIF kurang dari 10. Dengan demikian dapat disimpulkan bahwa dalam model regresi tersebut tidak terdapat masalah multikolinearitas, maka model regresi ini layak untuk dipakai

\section{Uji Heterokedastisitas}

Model regresi yang baik tidak terjadi adanya heteroskedastisitas. Cara yang digunakanuntuk mendeteksi heteroskesdatisitas adalah menggunakan uji scatterplot. Berdasarkan gambar dapat diketahui bahwa data (titiktitik) menyebar secara merata di atas dan di bawah garis nol, tidak berkumpul di satu tempat, serta tidak membentuk pola tertentu sehingga dapat disimpulkan bahwa uji regresi ini tidak terjadi masalah heteroskedastisitas.

\section{Uji Regresi Berganda}

Hasil uji regresi linear berganda terhadap ketiga variabel independen, yaitu kesadaran wajib pajak, pelayanan fiskus dan sanksi pajak menunjukkan hasil sebagai berikut: konstanta0,7394; kesadaran wajib pajak 0,032; pelayanan fiskus 0,268; sanksi pajak 0,227. Dari hasil ini dapat disusun persamaan regresinya:

$$
\mathrm{Y}=7.394+0.032 \mathrm{X}_{1}+0.268 \mathrm{X}_{2}+0.227 \mathrm{X}_{3}+e t
$$


Nilai konstanta dengan koefisien regresi pada tabel diatas dapat dijelaskan sebagai berikut:

1. Konstanta sebesar 7,394 menunjukkan bahwa jika variabel-variabel independen (kesadaran wajib pajak, pelayanan fiskus, dan sanksi pajak) diasumsikan tidak mengalami perubahan (konstan) maka nilai Y (kepatuhan wajib pajak) adalah sebesar

$7,394 \%$.

2. Koefisien variabel kesadaran wajib pajak (X1) sebesar 0,032 berarti setiap kenaikan kesadaran wajib pajak sebesar $1 \%$, maka kepatuhan wajib pajak akan naik sebesar $0,032 \%$.

3. Koefisien variabel pelayanan fiskus (X2) sebesar 0,268 berarti setiap kenaikan kesadaran wajib pajak sebesar $1 \%$, maka kepatuhan wajib pajak akan naik sebesar $0,268 \%$.

4. Koefisien variabel sanksi pajak (X3) sebesar 0,227 berarti setiap kenaikan kesadaran wajib pajak sebesar $1 \%$, maka kepatuhan wajib pajak akan naik sebesar 0,227\%.

\section{Uji Koefisien Determinasi}

Koefisien Determinasi adalah bagian dari variasi total dalam variabel dependen yang dijelaskan oleh variasi dalam variabel independen. Untuk melihat nilai dari koefisien determinasi pengolahan data melalui SPSS dapat dilihat pada tabel model summary yang menunjukkan nilai $\mathrm{R}$ sebesar 0,487 berarti hubungan antara variabel independen terhadap variabel dependen sebesar48,7\%.Hal ini variabel Kesadaran Wajib Pajak, Sanksi Pajak dan Pelayanan Fiskus memiliki hubungan yang cukup kuat dengan Kepatuhan Wajib Pajak. Pada Adjusted $R$ Square diperoleh nilai sebesar 0,225. Ini berartiVariabel Kesadaran Wajib Pajak, Sanksi Pajak dan Pelayanan Fiskus mempengaruhi Kepatuhan Wajib Pajak yaitu sebesar 22,5\%. Sedangkan sisanya 77,5\% dipengaruhi oleh faktor- faktor lain seperti sosialisasi perpajakan, sikap rasional, lingkungan, pemahaman wajib pajak, dan sebagainya.

\section{Uji Hipotesis}

\section{Hipotesis}

$\mathrm{H}_{0}=$ Tidak ada Pengaruh Kesadaran Wajib Pajak, Pelayanan Fiskus dan Sanksi Pajak Terhadap Kepatuhan Wajib Pajak Orang Pribadi Di Fakultas Teknik Universitas Sriwijaya

$\mathrm{H}_{1}=$ Ada Pengaruh Kesadaran Wajib Pajak, Pelayanan Fiskus dan Sanksi Pajak Terhadap Kepatuhan Wajib Pajak Orang Pribadi Di Fakultas Teknik Universitas Sriwijaya. 


\section{Uji F}

Uji $\mathrm{F}$ digunakan untuk mengetahui pengaruh variabel bebas terhadap variabel terikat secara keseluruhan.Uji F dilakukan berdasarkan nilai probabilitas. Jika nilai signifikan lebih kecil dari 0,05 maka Ho ditolak, artinya ada pengaruh yang signifikan dari variabel independen terhadap variabel dependen. Sedangkan jika nilai signifikan lebih besardari 0,05 maka Ho diterima, artinya tidak ada pengaruh yang signifikan dari variabel independen terhadap variabel dependen. Hasil uji F menunjukkan nilai F hitung sebesar 19,108 dengan signifikan sebesar 0,000. Nilai signifikan tersebut lebih kecil daripada 0,05, sehingga hal tersebut menunjukkan bahwa variabel independen berpengaruh secara simultan terhadap variabel dependen. Artinya, setiap perubahan yang terjadi pada variabel independen yaitu kesadaran wajib pajak, pelayanan fiskus, dan sanksi pajak secara bersama-sama akan berpengaruh pada kepatuhan wajib pajak di Fakultas Teknik Universitas Sriwijaya.

\section{SIMPULAN}

Berdasarkan hasil analisis yang telah dilakukan, maka penulis dapatmengambil beberapa kesimpulan sebagai berikut: 1) Kesadaran wajib pajak berpengaruh positif tetapi tidak signifikan terhadap kepatuhan wajib pajak. Hal ini menunjukkan bahwa makin tinggi kesadaran wajib pajak, maka kepatuhan wajib pajak pun akan tinggi tetapi tidak signifikan. 2) Pelayanan fiskus pajak berpengaruh positif dan signifikan terhadap kepatuhan wajib pajak. Hal ini menunjukkan bahwa makin tinggi pelayanan fiskus, maka kepatuhan wajib pajak pun akan tinggi. 3) Sanksi Pajak berpengaruh positif dan signifikan terhadap kepatuhan wajib pajak. Hal ini menunjukkan bahwa makin tinggi sanksi pajak, maka kepatuhan wajib pajak pun akan tinggi

\section{DAFTAR PUSTAKA}

Arikunto, S. 2010. Prosedur penelitian : Suatu Pendekatan Praktik. (Edisi.Revisi).Jakarta : Rineka Cipta.

Arum, Harjanti P. 2012. Pengaruh Kesadaran Wajib Pajak, Pelayanan Fiskus dan Sanksi Perpajakan terhadap Kepatuhan Wajib Pajak Orang Pribadi yang Melakukan Kegiatan Usaha Dan Pekerjaan Bebas. (Online)Jurnalvolume 1, Nomor 1, tahun 2012. Universitas Diponegoro. 
Ghozali, Imam. 2011. "Aplikasi Analisis Multivariate Dengan Program SPSS". Semarang: Badan Penerbit Universitas Diponegoro.

Ilyas, W. B. dan Burton, R. 2008.Hukum Pajak (Edisi 4). Jakarta: Salemba Empat.

Manik Asri, Wuri. 2009. "Pengaruh Kualitas Pelayanan, Biaya Kepatuhan Pajak,dan Kesadaran Wajib Pajak pada Kepatuhan Pelaporan Wajib Pajak Badan yang Terdaftar di Kantor Pelayanan Pajak Madya Denpasar".(Online), Skripsi Jurusan Akuntansi Pada Fakuttas EkonontiUniversitas Udayana.

Mardiasmo. 2011.Perpajakan. Edisi Revisi 2011.Yogyakarta: Penerbit Andi.

Muliari, N. K. dan Setiawan, P. E. 2010.Pengaruh Persepsi tentang Sanksi Perpajakan dan Kesadaran Wajib Pajak pada Kepatuhan Pelaporan Wajib Pajak Orang Pribadi di Kantor Pelayanan Pajak Pratama Denpasar Timur, (Online),Jurnal Akuntansi dan Bisnis: Fakultas EkonomiUniversitas Udayana.

Priantara, Diaz. 2012. Perpajakan Indonesia (Edisi 2). Jakarta: Mitra Wacana Media.

Rahayu, Siti Kurnia. 2010.Perpajakan Indonesia: Konsep dan.Aspek Formal. Yogyakarta: Graha Ilmu.

Santi, A. N. 2012. Analisis Pengaruh kesadaran Perpajakan, Sikap Rasional, Lingkungan, Sanksi Denda, dan Sikap Fiskus Terhadap kepatuhan Wajib Pajak, (Online).

Suandy, Erly. 2011. Hukum Pajak. Edisi 5, Jakarta: Salemba Empat.

Sugiyono. 2011. Metode Penelitian Kuantitatif, Kualitatif dan R\&D. Bandung: Alfabeta.

Sujarweni, V. Wiratna. 2014. Metodologi Penelitian. Yogyakarta: Pustaka Baru. 81

Supadmi. 2010. Meningkatkan Kepatuhan Wajib Pajak Melalui Kualitas.(Online),Jurnal Akuntansi dan Bisnis: Fakultas EkonomiUniversitas Udayana.

Tiraada, Tryana A. M. 2013. Kesadaran Perpajakan, Sanksi Pajak, Sikap Fiskus terhadap Kepatuhan WPOP di Kabupaten Minahasa Selatan. JurnalEMBA. Vol. 1. No. 3 September 2013.

Undang-Undang No.28 Tahun 2007 tentang Perubahan Ketiga atas Undang-Undang No.6 Tahun 1983 tentang Kententuan Umum dan Tata Cara Perpajakan (KUP)

Widayati dan Nurlis. 2010. Faktor-faktor yang Mempengaruhi Kemauan untuk Membayar Pajak Wajib Pajak Orang Pribadi yang Melakukan Pekerjaan Bebas. (Online) Jurnal SNA XIII. 
Winerungan, O. L. 2013. Sosialisasi Perpajakan, Pelayanan Fiskus dan Sanksi Perpajakan Terhadap Kepatuhan WPOP di KPP Manado dan KPP Bitung. (Online) Jurnal EMBA: Fakultas Ekonomi dan Bisnis UniversitasSam Ratulangi Manado, Vol. 1, No. 3.

Yadnyana, I Ketut. 2009. Pengaruh Moral dan Sikap Wajib Pajak pada Kepatuhan Wajib Pajak Koperasi di Kota Denpasar.(Online), FakultasEkonomi Universitas Udayana, Denpasar 